\title{
Persistent cutaneous canine leishmaniasis caused by Leishmania (Viannia) braziliensis in an area with predominance of Nyssomyia neivai in the state of São Paulo, Brazil
}

\author{
Leishmaniose cutânea canina persistente causada por Leishmania (Viannia) \\ braziliensis em uma área com predomínio de Nyssomyia neivai no estado de \\ São Paulo, Brasil
}

André Antonio Cutolo; Gabriela Motoie ${ }^{1}$; Ingrid Menz²; Vera Lucia Pereira-Chioccola ${ }^{1 *}$ (1)

${ }^{1}$ Centro de Parasitologia e Micologia, Instituto Adolfo Lutz - IAL, São Paulo, SP, Brasil

Veterinário Autônomo, Campinas, SP, Brasil

How to cite: Cutolo AA, Motoie G, Menz I, Pereira-Chioccola VL. Persistent cutaneous canine leishmaniasis caused by Leishmania (Viannia) braziliensis in an area with predominance of Nyssomyia neivai in the state of São Paulo, Brazil. Braz J Vet Parasitol 2021; 30(3): e007121. https://doi.org/10.1590/S1984-29612021074

\begin{abstract}
American cutaneous leishmaniasis (ACL) is a neglected zoonotic disease caused mainly by Leishmania (Viannia) braziliensis, which is endemic throughout Brazil. Canine ACL cases were investigated in a rural area of Monte Mor, São Paulo, where a human ACL case had been confirmed. Dogs were evaluated through clinical and laboratory diagnosis including serology, cytological tissue preparations and PCR on skin lesions, lymph node and bone marrow samples. Entomological investigations on sandflies trapped in the surroundings of the study area were performed for 14 months. Nyssomyia neivai was the predominant phlebotomine species, comprising $94.65 \%$ of the captured specimens (832 out of 879). This species was the most abundant in all trapping sites, including human homes and dog shelters. Ny. whitmani, Migonemyia migonei, Pintomyia monticola, Evandromyia cortellezzii, Pi. fischeri and Expapilata firmatoi were also captured. Two of the three dogs examined were positive for anti-Leishmania IgG in ELISA using the antigen Fucose mannose ligand and skin samples were positive for $L$. (V.) braziliensis in PCR, but all the samples collected were negative for $L$. ( $L$.) infantum. One of the dogs had a confirmed persistent infection for more than one year.
\end{abstract}

Keywords: Dogs, Leishmania (Viannia) braziliensis, American cutaneous leishmaniasis, laboratory diagnosis, phlebotomine sandflies.

\begin{abstract}
Resumo
A leishmaniose tegumentar Americana (LTA) é uma doença zoonótica negligenciada, causada principalmente por Leishmania (Viannia) braziliensis, sendo endêmica em todo o Brasil. Foram investigados casos de LTA canina em uma área rural da cidade de Monte Mor, São Paulo, onde foi confirmado um caso humano de LTA. Os cães foram avaliados por diagnóstico clínico e laboratorial, incluindo sorologia, esfregaços microscópicos e PCR de amostras em lesões de pele, linfonodos e medula óssea. Também foram realizadas investigações entomológicas durante 14 meses, usando-se armadilhas luminosas para flebotomíneos nas proximidades da área de estudo. Nyssomyia neivai foi a espécie de flebotomíneo predominante com $94,65 \%$ dos espécimes capturados ( 832 de 879 ). Essa espécie foi a mais abundante em todos os locais de captura, incluindo-se abrigos para humanos e cães. Foram também capturadas as espécies Ny. whitmani, Migonemyia migonei, Pintomyia monticola, Evandromyia cortellezzii, Pi. fischeri e Expapilata firmatoi. Dos três cães examinados, dois apresentaram IgG anti-Leishmania positivo no ELISA,
\end{abstract}

Received May 24, 2021. Accepted August 5, 2021

*Corresponding author: Vera Lucia Pereira-Chioccola. E-mail: pchioccola@gmail.com.

This is an Open Access article distributed under the terms of the Creative Commons Attribution License, which permits unrestricted use distribution, and reproduction in any medium, provided the original work is properly cited. 
usando-se o antígeno "Fucose mannose ligand", PCR da lesão de pele positivo para L. (V.) braziliensis e negativo em todas amostras para L. (L.) infantum. Um dos cães apresentou infecção persistente por mais de um ano.

Palavras-chave: Cães, Leishmania (Viannia) braziliensis, leishmaniose tegumentar Americana, diagnóstico laboratorial, flebotomíneos.

\section{Introduction}

Leishmaniases are caused by parasites from the Leishmania genus and consist of a group of chronic diseases generally transmitted from animals to humans by the bite of infected female sandflies. There is a broad spectrum of clinical forms, including those that affect skin, mucosa and internal organs. The two most common clinical forms are visceral leishmaniasis (VL), which compromises internal organs with high lethality in untreated hosts, and cutaneous leishmaniasis (CL). The cutaneous form is mostly characterized by skin lesions, mainly ulcers, on exposed parts of the body, which leave life-long scars, eventually progressing to a mucocutaneous form that invades the mucous membranes of the upper respiratory tract, causing gross mutilation by destroying tissues in the nose, mouth and throat, causing also serious psychological problems among these patients (Alvar et al., 2012; Goto \& Lauletta Lindoso, 2012; WHO, 2015).

Around $95 \%$ of $\mathrm{CL}$ cases occur in the Americas, the Mediterranean basin, the Middle East and Central Asia. In 2018 , over $85 \%$ of new CL cases (600,000 to one million per year) occurred in 10 countries worldwide (WHO, 2021). The epidemiology of $C L$ in the Americas is very complex, with variations in transmission cycles, reservoir hosts, phlebotomine sandflies, clinical manifestations and response to therapy; and multiple Leishmania species circulate in the same geographical area (WHO, 2021). CL is widely distributed from northern Argentina to the southern USA and is called American cutaneous leishmaniasis (ACL). In Brazil, around 28,000 new ACL cases are registered annually (Brasil, 2017). In the state of São Paulo (Brazil), the incidence of ACL has increased, and at present time, the incidence rate is approximately 350 new human cases notified per year, in 400 different municipalities (CVE, 2021). These endemic regions are characterized by old human settlements with no occupational characteristics. The zoonotic transmission cycles occur in peri-urban and/or urban areas associated with domestic and/or synanthropic animals (Tolezano, 1994).

The most common ACL agent in Brazil, including the state of São Paulo, is Leishmania (Viannia) braziliensis. The main vectors are phlebotomine sandflies belonging to the Nyssomyia intermedia complex, like Ny. intermedia and Ny. neivai. Other vectors, such as Ny. whitmani, Migonemyia migonei, Pintomyia fischeri and Pi. pessoai are considered to be secondary vector species (Gomes, 1994; Camargo-Neves et al., 2002; Lainson \& Rangel, 2005).

Besides being the main domestic reservoir for L. (L.) infantum, (Lainson \& Rangel, 2005; Brasil, 2014), dogs have been found naturally infected by other Leishmania species, such as L. (V.) braziliensis (Gomes et al., 2007; Dantas-Torres, 2011) and L. (L.) amazonensis (Tolezano et al., 2007; Brasil, 2017) in São Paulo state. Thus, the diversity of species causing ACL and the role of domestic dogs as reservoirs, near the human domiciles and its surroundings remain to be elucidated.

The identification of Leishmania species in infected dogs is appropriate for an accurate diagnosis, with the aim of mitigating the risk of human infection, especially in areas silent and/or vulnerable for VL, where transmission cycles of $L$. (V.) braziliensis occur. Domestic animals such as dogs may act as good risk indicators in these areas (Gomes et al., 2007).

Given that there are few recent reports of natural foci of zoonotic L. (V.) braziliensis transmission in the state of São Paulo, this study describes the clinical and laboratory findings that determined this diagnosis among dogs, in relation to a human $A C L$ case. In addition, this study includes an investigation of the phlebotomine fauna in the same area as the ACL cases, over a 14-month period of active trapping.

\section{Materials and Methods}

\section{Ethics statement}

This study was performed, after approval (Protocol: CEUA-IAL 06/2014) and in accordance with the recommendations of the Ethics Committee for Animal Use of the Adolfo Lutz Institute (Comissão de Ética no Uso de Animais do Instituto Adolfo Lutz, CEUA-IAL) that is based in recommendations of the National Experimentation Control Council (Conselho Nacional de Controle de Experimentação, CONCEA). 


\section{Study area}

The study area consisted of a small farm located near the Capivari River ( $22^{\circ} 59^{\prime} 12^{\prime \prime}$ South and $47^{\circ} 23^{\prime} 03^{\prime \prime}$ West; altitude of 528 meters) in the municipality of Monte Mor, state of São Paulo, on the border with the municipalities of Elias Fausto and Capivari, next to highway SP 101, which connects Campinas to Monte Mor and Capivari cities. Figure 1 shows the location of Monte Mor and the exact location of the rural property and where the human and canine cases occurred. The site was a simple masonry house, with an unlined roof that allowed insects to enter the dwelling. The house was about 5 meters from the edge of the Atlantic riparian forest of the Capivari River. This forest had 5 to 30 meters wide along of the river and the study area. Surrounding the house (5 to 20 meters) there was a kennel, which lived three adult mongrel female dogs.

\section{Sample collection and clinical diagnosis}

In July 2010, the veterinarian of the Center for Zoonosis Control of the municipality of Monte Mor has been investigated suspected cases of canine visceral leishmaniasis (CVL) in a rural area. A woman who owned three dogs $(A, B, C)$ had previously been diagnosed as having $A C L$, with a cutaneous ulcer on the posterior surface of the right thigh, as shown in Figure $2 \mathrm{E}$. She also presented to the veterinarian the result of a positive indirect immunofluorescence test (IFAT) for ACL. She stated that dogs had persistent lesions on their ears and muzzle, despite treatment with topical antibiotics.

One month later (August 2010), the dogs were clinically examined and restrained for clinical sample collection. They were sedated subcutaneously with acepromazine $(0.2 \%$ Acepran $\mathbb{B} ; 0.5 \mathrm{mg} / \mathrm{kg})$ and either butorphanol (Torbugesic $® ; 0.1 \mathrm{mg} / \mathrm{kg}$ ). All dogs also received $1 \%$ lidocaine subcutaneously in the skin. Blood samples were collected from the jugular vein $(5 \mathrm{~mL})$ using plastic vacutainer tubes without anticoagulant, to obtain serum. Biopsies were obtained from lymph nodes, bone marrow and the active skin lesions. The biopsies fragments were divided into two aliquots. One of them was placed on glass slides, fixed in methanol and stained with Giemsa. The other was transferred to a tube containing a buffered saline solution and was used for DNA extraction and polymerase chain reaction (PCR).

Further clinical evaluations were done after the first inspection, 15, 60 and 90 days later. After 16 months of the first inspection, clinical and laboratory evaluations were again performed on dogs A and C. Blood collections were obtained for serological tests. Biopsies of skin lesions, lymph node and bone marrow were obtained for PCR.

\section{Laboratory diagnosis}

For the parasitological diagnosis, imprints of skin lesions, lymph node and bone marrow were fixed on glass slides with methanol and stained with Giemsa. These samples were analyzed under a microscope (magnification $1,000 \mathrm{x})$.

For serological diagnosis, the reactions were performed on serum samples using IIR (Bio-Manguinhos); an immunochromatographic test (IT) with the antigen k29 (k26, k39 and k9-DPPTM Leishmania test; Bio-Manguinhos); and ELISA using three different antigens: i) heat shock protein $70 \mathrm{Kd}$ (HSP70) (S7 antigen); ii) fucose mannose ligand (FML); and iii) Leishmania major-like (Bio-Manguinhos). Reactions were performed as manufacturer's instructions. IIR and IT were manufactured only for CVL diagnosis.

For molecular diagnosis, before performing the DNA extraction, canine samples were crushed and digested in a lysis buffer (Tris-HCl, 10 mM, pH 8.0; EDTA 10 mM; SDS, 0.5\%; N-lauryl sarkosyl, 0.01\%; and proteinase K, 100 mg/ $\mathrm{mL}$ ). Then, samples were incubated in water bath at $56^{\circ} \mathrm{C}$ until tissues were lysed (2 to $18 \mathrm{~h}$ ) (Gomes et al., 2008). Next, DNA samples were extracted using the QIAamp DNA mini-kit (Qiagen), as the manufacturer's instructions. DNA concentrations and purity were determined by means of the optical density (O.D.) ratio at 260 and $280 \mathrm{~nm}$ in a NanoDrop ND1000 (Thermo Scientific).

Leishmania spp. was identified by PCR using the primer pair 150/152 (Passos et al., 1999), which amplifies 120 bp from a conserved region of kDNA minicircles of Leishmania spp. Presence of $L$. (L.) infantum was investigated by using the primer pair RV1/RV2 (Lachaud et al., 2002; Gomes et al., 2007), which amplifies 145 bp of kDNA minicircles. L. (V.) braziliensis complex was investigated by amplification of a fragment that ranged from 146 to $149 \mathrm{bp}$ from the multicopy spliced leader RNA gene using the primer pair LU-5A/LB-3C (Harris et al., 1998; Gomes et al., 2008). To verify the quality of the extracted DNA and presence of PCR inhibitors, all samples were assayed using PCR that amplifies a housekeeping gene (911-bp fragment) of the canine glyceraldehyde-3-phosphate dehydrogenase 
gene using the primer pair GAPDH4F/GAPDH4R (Colombo et al., 2015). The reactions were run following the same conditions as described before (Gomes et al., 2007). Each amplification run contained one negative control (ultra-pure water) and one positive control (DNA extract of L. (V.) braziliensis promastigotes (WHO reference strainMHOM/BR/75/2903). After thermal cycles, PCR products were electrophoresed in $2 \%$ agarose gel and stained with ethidium bromide. Amplified products were made visible by UV illumination, and images were analyzed by a Syngene GeneSnap Imager, version 6.05.01. The sizes of fragments were based on comparison to a 100-bp ladder.

\section{Entomological investigations}

From September 2011 to October 2012, entomological investigations were carried out in the ACL area and its surroundings, with a total of 240 hours of trapping effort. Two different rural properties were evaluated. The locations of these properties are shown in Figure 1. The first site was where the ACL cases had been diagnosed (Figure 1C). The second was a small property about $2 \mathrm{~km}$ away from the first one. Automatic light traps were used overnight (from dusk to the morning of the next day), inside human dwellings, kennels, a chicken coop, a pig pen and a corral with cattle and at sites with natural vegetation close to human homes and animal shelters. On a single occasion, a Shannon trap was used besides the pig pen from 6 to 11 PM.
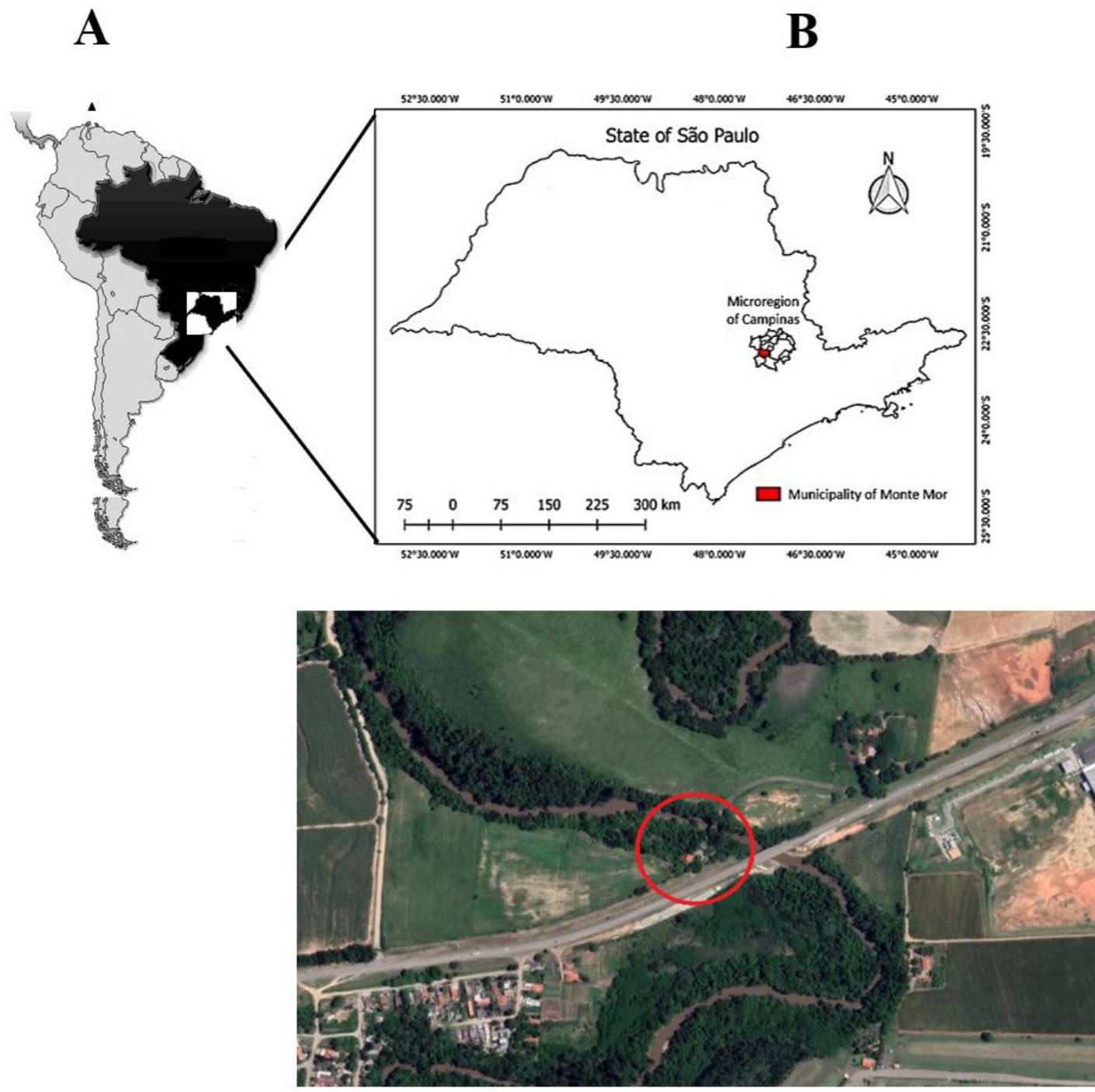

Figure 1. Map of South America and Brazil (A), São Paulo and municipality of Monte Mor (in red) located within the metropolitan region of Campinas city (B). The rural property where the ACL focus was identified is inside the red circle (C). The Capivari River and the residual riparian Atlantic forest in the close vicinity of the human/dog dwelling is shown together the agricultural/peri-urban landscape surroundings (latitude $22^{\circ} 59^{\prime} 13.65^{\prime \prime} \mathrm{S}$ and longitude $47^{\circ} 23^{\prime} 04.05^{\prime \prime}$ W; altitude $528 \mathrm{~m}$ ). The image was acquired through Google Earth, Google Inc, with permission as described on the website (Google Inc, 2021). 


\section{Phlebotomine sandflies: sample collection and identification}

A total of 8 episodes of insect capture (September 15, 2011; October 10, 2011; February 1, 2012; March 1, 2012; March 19, 2012, April 5 and 6, 2012; May 5, 2012; and October 1, 2012) were performed. The insects captured were killed by keeping them cold. The sandflies were separated from the other insects and were screened using a magnifying glass to distinguish males and females. They were then fixed, dissected, stained and mounted on glass slides. Species identification was done in accordance with the taxonomic key of Galati (2003).

\section{Results}

\section{Clinical and laboratory diagnosis}

In August 2010, the clinical examination of three dogs showed that none of them presented any systemic clinical signs compatible with CVL. Dog A had a cutaneous ulcer ( $1.5 \mathrm{~cm}$ diameter) with raised borders, inside the right ear and two crustal lesions ( 0.5 and $1.0 \mathrm{~cm}$ diameter), inside the left ear (Figure 2A). ELISA/FML was positive. Dog B had a ulcerated lesion $(0.5 \mathrm{~cm}$ diameter) inside the right ear and one crusted lesion $(0.2 \mathrm{~cm}$ diameter) inside the left ear. However, all laboratory tests were negative. Dog $\mathrm{C}$ had a $0.5 \mathrm{~cm}$ circular cutaneous ulcer in the dorsal nasal
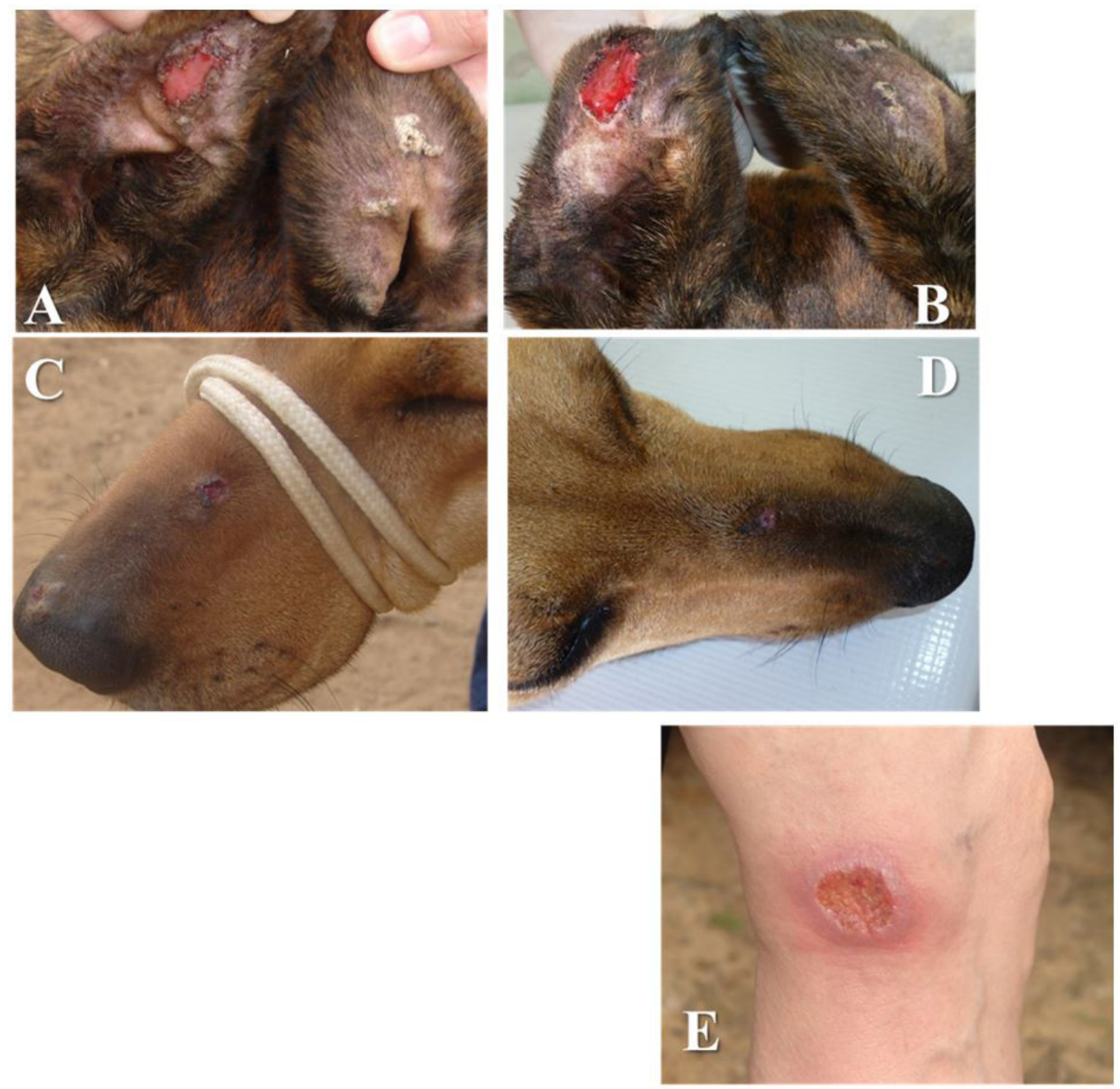

Figure 2. Lesions caused by L. (V.) braziliensis in dogs (August 2010): Dog A with a lesion and crusts on the inner side of ears (A). Dog C with a lesion in the dorsal nasal region (C). In November 2011, 16 months after the first inspection, the lesions were found to have been stable throughout the observational period, in $\operatorname{dog} A(B)$ and $\operatorname{dog} C(D)$. Cutaneous ulcer on the left leg of the dog owner, diagnosed as ACL (E). 
region and a small crusted lesion on the muzzle (Figure 2C) and presented a positive ELISA/FML test. The results from the laboratory tests on the canine samples are shown in Table 1.

The three dogs had negative results from cytological examination under a microscope and negative PCR for L. (L.) infantum in the bone marrow and lymph nodes biopsies. Only dog C had positive PCR for Leishmania spp. and $L$. $(V$.$) braziliensis complex in skin lesions, but not in samples from lymph nodes and bone marrow. Figure 3A$ shows the amplified products of $L$. (V.) braziliensis complex.

Seventy-five days after the first clinical evaluation, Dog A persisted with an ulcerated lesion in the right ear and crusted lesions in the left ear. Dog B presented healed lesions in the ears. Dog C had a crusted lesion on the previously diagnosed ulcer.

Sixteen months later, FML/ELISA was positive for dogs A and C. The other serological tests were negative. PCR for Leishmania spp. and Leishmania $(V$.$) braziliensis complex were positive on skin lesions, but not on lymph nodes and$ bone marrow samples from dogs A and C. Figure 3B shows the amplified products of $L$. (V.) braziliensis complex. We considered that the dogs were infected by $L$. $(V$.) braziliensis since this is the main causative agent of $A C L$ and the only species from subgenus Viannia identified so far in the state of São Paulo.

Table 1. Laboratory diagnosis of clinical samples collected from three dogs in the municipality of Monte Mor (São Paulo, Brazil).

\begin{tabular}{|c|c|c|c|c|c|c|c|c|}
\hline \multicolumn{2}{|l|}{ Methods } & \multirow{2}{*}{$\frac{\text { Parasitological }^{1}}{\text { imprint }}$} & \multirow{2}{*}{$\begin{array}{c}\text { Molecular }^{2} \\
\text { PCR } \\
\text { L. (V.) braziliensis } \\
\text { complex }\end{array}$} & \multicolumn{5}{|c|}{ Serological ${ }^{3}$} \\
\hline $\begin{array}{l}\text { Collection } \\
\text { Date }\end{array}$ & Dogs & & & $\begin{array}{l}\text { FML } \\
\text { ELISA }\end{array}$ & $\begin{array}{c}\text { S7 } \\
\text { ELISA }\end{array}$ & $\begin{array}{c}\text { ELISA } \\
\text { L. major }\end{array}$ & IIR & IT \\
\hline \multirow{4}{*}{ Aug /2010 } & A & Neg & Neg & Pos & Neg & Neg & Neg & Neg \\
\hline & B & Neg & Neg & Neg & Neg & Neg & Neg & Neg \\
\hline & C & Neg & Pos & Pos & Neg & Neg & Neg & Neg \\
\hline & $A$ & ND & Pos & Pos & ND & Neg & Neg & Neg \\
\hline Nov/2011 & C & ND & Pos & Pos & ND & Neg & Neg & Neg \\
\hline
\end{tabular}

Negative, Neg. Positive, Pos. ND, non-determined. ${ }^{1}$ Tests were done in skin lesions, lymph node and bone marrow biopsies; ${ }^{2}$ PCR was performed on skin lesions; ${ }^{3} \mathrm{FML}$, fucose mannose ligand antigen; S7, heat shock protein $70 \mathrm{Kd}$; IIR, indirect immunofluorescence reaction; IT, immunochromatographic test.

\section{L. (V.) braziliensis complex}

A

\section{Aug /2010}

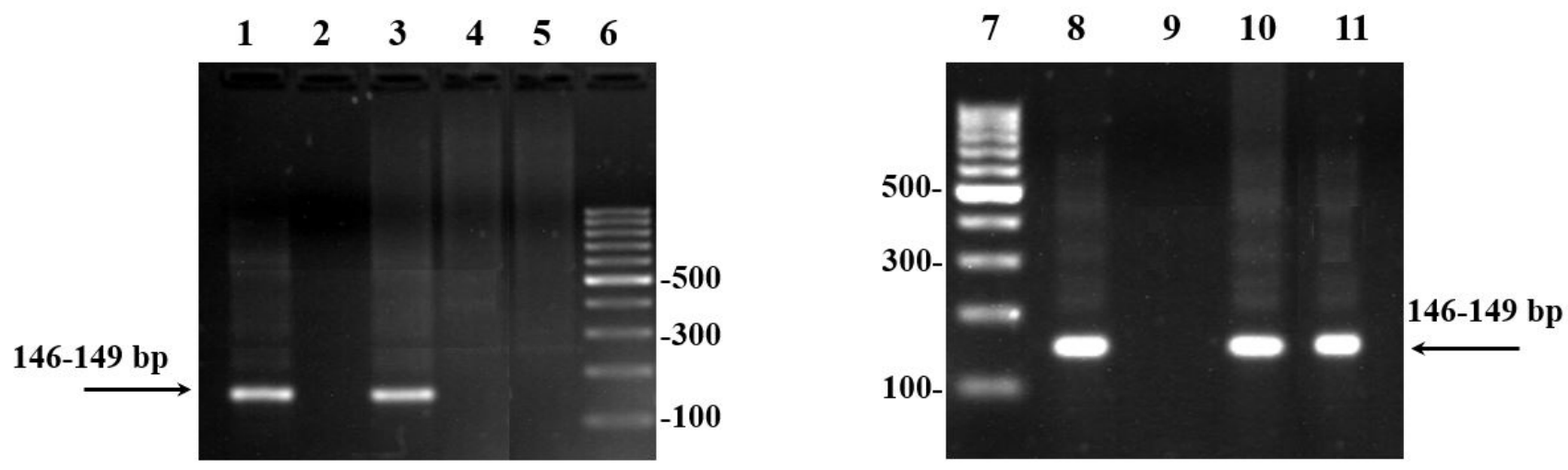

B Nov $/ 2011$

Figure 3. L. (V.) braziliensis identification was performed using the LU-5A/ LC-3L primer pair that amplified a 145-149 bp product from a variable non-transcribed spacer, and specific region from the SL-RNA gene. The amplified products were analyzed in electrophoresis in 2\% agarose gel. A, samples collected in Aug/2010 and B, samples collected in Nov/2011. Gel lanes 1 and 8, positive control, L. (V.) braziliensis promastigotes; lanes 2 and 9, negative control; lines 3 and 10, dog C; lines 4 and 11, dog A; line 5, dog B; and lines 6 and 7, 100 bp ladder. 
PCR for L. (L.) infantum was negative on all samples, including samples of the bone marrow and lymph nodes. The cutaneous lesions of $\operatorname{dog}$ A (Figure 2B) were stable, while $\operatorname{dog} C$ presented a discrete ulcer on the nasal area (Figure 2D)

\section{Entomological investigations}

The results from the entomological investigation carried out are described in Table 2. A total of 879 specimens of sandflies were captured and identified during 240 hours of trapping, considering all the traps used.

Among the 879 insects captured at the ACL area, seven distinct species were identified: $N y$. neivai was the most abundant species at all trapping sites including human dwellings and kennels, totaling 832 (94.65\%) specimens captured; Mi. migonei, 27 specimens (3.07\%); Ny. whitmani, 12 specimens (1.37\%); Pintomyia monticola, 4 specimens (0.46\%); Evandromyia cortellezzii, 2 specimens (0.23\%); Pi. fischeri and Expapillata firmatoi with only one identified specimen of each species.

\section{Discussion}

The original hosts of Leishmania species on the natural foci are wild mammals that normally do not present clinical abnormalities of the infection. This wild enzootic cycle is maintained between these vertebrates and sandflies, with no involvement of humans as host. Anthropic changes on the natural landscape may implicate in changes on demography, distribution and dynamics of wild vertebrate reservoirs and sandflies that can become more abundant near human habitations, connecting parasites once restricted to wild areas to new areas, allowing domestic dogs to potentially play not only a role sources of infection but also reservoirs to different species of Leishmania, like those causing $\mathrm{ACL}$, in the peridomicile, which might increase the risk of transmission to humans (Roque \& Jansen, 2014). The increasing and amazing adaptation of Lutzomyia longipalpis to the urban environment with the domestic dogs acting as main reservoir of $L$. (L.) infantum allowed that urban and peri-urban environments became established natural foci of $\mathrm{VL}$, with no involvement of wild animals as reservoirs anymore (Lainson \& Rangel, 2005; Brasil, 2014.) Despite the parasitism in different organs and severe clinical abnormalities on the dog, cutaneous parasitism by $L$. (L.) infantum amastigotes is usually present, even in healthy skin, and infected dogs are then an important source of infection for Lu. longipalpis during their blood feeding, which favors parasite transmission to humans in the domiciliary environment (Grimaldi \& Tesh, 1993; Lainson \& Shaw, 1998; Lainson \& Rangel, 2005; Baneth et al., 2008).

In Brazil, elucidation of the epidemiological importance of dogs in the transmission chain of human $A C L$ is very important. Besides L. (V.) braziliensis, other species such as L. (V.) guyanensis, L. (V.) panamensis, L. (V.) peruviana and L. (L.) amazonensis are causative agents of ACL in dogs (Lainson \& Shaw, 1998). Studies have shown that in some

Table 2. Phlebotomine sand fly species captured in the municipality of Monte Mor (São Paulo, Brazil). The study on this area and its surroundings was performed between September 2011 and October 2012.

\begin{tabular}{|c|c|c|c|c|c|c|c|c|c|c|c|c|c|c|c|c|}
\hline \multirow{2}{*}{ Sandyfly species } & \multicolumn{2}{|c|}{$\begin{array}{l}\text { Human } \\
\text { house }\end{array}$} & \multicolumn{2}{|c|}{$\begin{array}{c}\text { Dog } \\
\text { kennel }\end{array}$} & \multicolumn{2}{|c|}{$\begin{array}{l}\text { Chicken } \\
\text { coop }\end{array}$} & \multicolumn{2}{|c|}{ Pig pen } & \multicolumn{2}{|c|}{ Forest } & \multicolumn{2}{|c|}{ Corral } & \multicolumn{2}{|c|}{ Total } & \multirow[b]{2}{*}{ Total } & \multirow[b]{2}{*}{$\%$} \\
\hline & $\mathbf{M}$ & $\mathbf{F}$ & M & $\mathbf{F}$ & $\mathbf{M}$ & $\mathbf{F}$ & $\mathbf{M}$ & $\mathbf{F}$ & $\mathbf{M}$ & $\mathbf{F}$ & M & $\mathbf{F}$ & $\mathbf{M}$ & $\mathbf{F}$ & & \\
\hline Nyssomyia neivai & 12 & 10 & 43 & 23 & 261 & 93 & 121 & 84 & 125 & 54 & 4 & 2 & 566 & 266 & 832 & 94.65 \\
\hline Migonemyia migonei & - & 1 & - & - & 3 & 12 & 1 & 2 & 5 & 2 & 1 & 0 & 10 & 17 & 27 & 3.07 \\
\hline Nyssomyia whitmani & 1 & - & - & - & 1 & 4 & 3 & - & 1 & 1 & - & 1 & 6 & 6 & 12 & 1.37 \\
\hline Pintomyia monticola & 1 & - & - & - & - & - & - & - & - & 3 & - & - & 1 & 3 & 4 & 0.46 \\
\hline $\begin{array}{c}\text { Evandromyia } \\
\text { cortellezzii }\end{array}$ & - & - & - & 1 & - & - & - & - & - & 1 & - & - & 0 & 2 & 2 & 0.23 \\
\hline Expapilatta firmatoi & - & 1 & - & - & - & - & - & - & - & - & - & - & 0 & 1 & 1 & 0.11 \\
\hline Pintomyia fischeri & - & - & - & - & 1 & - & - & - & - & - & - & - & 0 & 1 & 1 & 0.11 \\
\hline Total & 14 & 12 & 43 & 24 & 266 & 109 & 125 & 86 & 131 & 61 & 5 & 3 & 584 & 295 & 879 & 100 \\
\hline
\end{tabular}


areas of Brazil, cases of VL and CL can coexist or involve canine infection caused by $L$. (V.) braziliensis, such as in Amazonia (Santos et al., 2020), in Bahia (Carvalho et al., 2015) and in Pernambuco (Dantas-Torres et al., 2010).

A campaign of active epidemiological surveillance of canine VL was carried out in the municipality of Monte Mor about 10 years ago, in which seven phlebotomine species were identified in the 16 different areas sampled. Among these species, the most abundant was Ny. neivai. However, Lu. longipalpis has never been captured in these areas. At the same time, a serological survey looking for the presence of anti-Leishmania IgG antibodies in dogs was performed randomly among 319 dogs living in different neighborhoods. No seropositive animal was found at that time (Cutolo et al., 2009). These findings confirmed the classification of the municipality as non-receptive and non-transmissive for $\mathrm{VL}$, according to the epidemiological classification set up by the National Program on Surveillance and Control of VL (CVE, 2021). Unfortunately, dogs with autochthonous VL have been identified in municipalities bordering Monte Mor, which shows the vulnerability of the area to colonization by Lu. longipalpis. This scenario reinforces the epidemiological situation of this municipality today (Cutolo et al., 2009; CVE, 2021).

As the three dogs of this study presented clinical abnormalities compatible with canine leishmaniasis, in October, 2010, the Zoonosis Control Service of Monte Mor performed an active search for other canine ACL cases in the area. Clinical inspections were done on 76 owned dogs in the surroundings of the study area. This inspection was done during an anti-rabies vaccination campaign. However, none of these 76 dogs had any lesions or clinical abnormalities compatible with CVL or canine ACL (data not shown).

Unlike VL, there are no specific control measures directed to dogs with ACL. Treatment with drugs for human use is not recommended due to the possibility of inducing drug resistance to Leishmania strains potentially shared with humans. Euthanasia is only indicated in terminal cases, for animal welfare reasons (Brasil, 2014). These measures led us to keep the dogs of this study together with their owners during the whole period of evaluations. From March 2011 onwards, the three dogs were wearing 4\% deltamethrin collars (Scalibor ${ }^{\circledR}$ ) as a repellent.

Confirmation that the causative agent of different suspected canine ACL cases was $L$. (V.) braziliensis may be obtained after euthanasia, from analysis of necropsy samples in different studies (Pires et al., 2014; Paz et al., 2018). In the present study, the dogs were followed up closely for 16 months. These clinical examinations, from the first (August 2010) until the last one (November 2011) allowed us to conclude that the natural infection was caused by L. $(V$.) braziliensis and that it was persistent in the dogs for the whole study period.

The role of dogs as a domestic reservoir for $L$. (V.) braziliensis is controversial. According to the Brazilian Ministry of Health, dogs are considered to be an accidental host for $L$. (V.) braziliensis with no specific control recommendations for them (Brasil, 2014). Moreover, several authors have discussed the role of dogs in the epidemiology of ACL and have asked whether dogs are a real reservoir of the parasite or just victims of the infection, like humans. The presence of dogs with ACL in areas with occurrences of human cases is a known fact (Padilla et al., 2002; Dantas-Torres, 2007; Pittner et al., 2009; Marquez et al., 2017). On the other hand, for decades, different authors have confirmed that dogs are susceptible to $L_{\text {. }}(V$.$) braziliensis, including with occurrence of this parasite in internal organs like the$ mesenteric lymph nodes, liver, spleen and bone marrow (Reithinger \& Davies, 1999; Dantas-Torres, 2007; DantasTorres, 2011; Marquez et al., 2017; Paz et al., 2018). The majority of the descriptions have included clinical findings restricted to cutaneous clinical abnormalities, like ulcers with raised borders with poor healing prognosis, which occur in different body parts. In dogs, these ulcers are located mainly on the face, internal side of ears, muzzle and scrotum. These sites, with exposed skin, are more accessible for the phlebotomine vectors to obtain their blood meals. Asymptomatic infected animals also have been described (Padilla et al., 2002; Madeira et al., 2003; Carvalho et al., 2015; Esteva et al., 2017).

Infected dogs usually show only host lower amounts of $L$. $(V$.) braziliensis amastigotes in cutaneous lesions, which makes it difficult to diagnose their presence through direct methods such as culture and imprint on glass slides (Falqueto et al., 1986; Padilla et al., 2002). It has been estimated that the amount of amastigotes forms in the skin lesions of dogs may be lower than what is found in human cutaneous lesions (Padilla et al., 2002). These findings point to the possibility that humans may represent a better source of infection for phlebotomine sandflies than dogs (Rojas \& Scorja, 1989; Padilla et al., 2002; Dantas-Torres, 2007).

Although serological techniques such as IFAT are specific, they have low sensitivity for identifying infected animals. Use of purified antigens may be an alternative for achieving higher diagnostic sensitivity (Padilla et al., 2002; Porrozzi et al., 2007). In this study, among the serological methods used, only ELISA/FML antigen was capable to confirm the infection. This result can be explained by the fact that the IFAT and IT test kits are manufactured for VL diagnosis. Although the FML antigen is a glycoprotein extracted from L. (L.) donovani promastigotes, these results are interpreted as cross-reactions, since this occurrence is well known. The considerable genetic diversity 
that exists between natural populations of Leishmania species can influence the expression of different surface antigens, thereby leading to cross-reactions (Cupolillo et al., 1998; Porrozzi et al., 2007).

Neither clinical examination nor the routine laboratory methods that are applied for diagnosing canine leishmaniasis, such as serological and parasitological methods using samples like serum samples and aspirates/ biopsies of lymph nodes and skin lesions, enable differentiation of Leishmania species. In L. (L.) infantum-free areas in Brazil, dogs presenting skin lesions must be properly evaluated by the veterinary public health service, using both clinical inspections and laboratory analysis, with the aim of correctly diagnosing the causative agent. These measures avoid misdiagnosis of possible introduced cases of VL that can potentially put at risk human communities through starting local zoonotic transmission and establishing the disease in a new area. Unfortunately, in Brazil dog culling is still a common practice adopted as a measure to control VL (Dantas-Torres et al., 2019). In this light, correct diagnosis also avoids the possibility of euthanasia of false-positive animals, since a serologically reactive dog may be infected only with $L$. (V.) braziliensis.

Molecular methods have been proven to be efficient for determining the presence, quantity and/or genotyping of Leishmania species that cause infections, since they are sensitive and specific (Gomes et al., 2007; Gomes et al., 2008; Cutolo et al., 2014). In this study, we reported identifying L. (V.) braziliensis in biopsied skin samples from dogs, from the border of active cutaneous lesions and from healing skin ulcers. Presence of Leishmania identified through PCR may be persistent in tissues from healed human lesions (scars), thus showing that clinical cure may not correspond to parasitological cure (Brasil, 2017). LU-5A/LB-3C primer set used in this study amplifies a 146-149 bp sequence from a gene of $L$. (V.) braziliensis complex, including the species $L$. (V.) braziliensis, L. (V.) guyanensis, L. (V.) panamensis, L. (V.) peruviana (Harris et al., 1998). Previous studies have shown the high sensitivity and specificity of this primer pair tested in crude extracts of dermal scrapings prepared from ulcerated lesions of confirmed cutaneous leishmaniasis from patients in South and Central America (Harris et al., 1998) and dogs in Brazil (Gomes et al., 2007). Since most of the of ACL cases in Brazil are caused by L. (V.) braziliensis (Grimaldi \& Tesh, 1993; Ramos-E-Silva \& De Moura Castro Jacques, 2002; Gomes et al., 2008), this primer pair was selected for this study.

Furthermore, our results showed that $L$. (L.) infantum was absent in the dog samples and one of the dogs had an active lesion for 16 months after the first diagnosis. Thus, presence of $L$. (V.) braziliensis was identified by PCR in two different occasions. This is the first time such persistency has been reported in dogs, to our knowledge. The infectivity of phlebotomine sandflies by feeding on the lesions and scars of dogs needs to be well investigated in order to better understand the possible role of dogs in the epidemiology of ACL. These results illustrate that PCR can be considered to be a viable quick diagnostic tool for supporting epidemiological investigations on leishmaniasis in the field, not only by the veterinary public control service, but also as a differential diagnostic method that could be used in private vet clinics.

Regarding the phlebotomine entomofauna identified in the study area, it was notable that at least four species that are considered potential vectors of the causative agent of ACL in the state of São Paulo were found. These were $N y$. neivai, Ny. whitmani, Mi. migonei and Pi. fischeri. The abundance and dominance of Ny. neivai in other areas of the state of São Paulo is well known (Camargo-Neves et al., 2002). This species has been found naturally infected by $L$. (V.) braziliensis in Brazil (Pita-Pereira et al., 2009). In addition to the abundance and predominance of this species over the other species present in all the traps in the study area, it was also found inside human homes and kennels, thus confirming its zoophilic and anthropophilic behavior. These characteristics are mandatory for Leishmania transmission among different host species and locations. This species is the probable vector of $L$. (V.) braziliensis in the focus studied here. Two newly encountered species are described for the first time in this municipality, Pi. fischeri and Ex. firmatoi. It is also worth mentioning that Ev. cortellezzii was identified in the kennels. Although only one specimen was found in association with the dogs, this phlebotomine species had previously been found in the urban area of Monte Mor, in opossum shelters located in the backyards of human houses (Cutolo et al., 2014). The association between Ev. cortellezzii and opossums or dogs shows the affinity of this phlebotomine species with these mammals. The hypothesis that Ev. cortellezzii may act as a link between sylvatic and urban/peri-urban cycles of transmission needs to be considered, since opossums are a potential wild reservoir for Leishmania spp.

\section{Acknowledgements}

To Roberto M. Hiramoto and group (Instituto Adolfo Lutz) for serological diagnosis in dog sera. To MSD for the donation of the deltamethrin collars used on the dogs during the study. VLP-C was supported by fellowships from CNPq (Conselho Nacional de Desenvolvimento Científico e Tecnológico, Brazil), number 302327/2018-5. 


\section{References}

Alvar J, Vélez ID, Bern C, Herrero M, Desjeux P, Cano J, et al. Leishmaniasis worldwide and global estimates of its incidence. PLoS One 2012; 7(5): e35671. http://dx.doi.org/10.1371/journal.pone.0035671. PMid:22693548.

Baneth G, Koutinas AF, Solano-Gallego L, Bourdeau P, Ferrer L. Canine leishmaniosis - new concepts and insights on an expanding zoonosis: part one. Trends Parasito/ 2008; 24(7): 324-330. http://dx.doi.org/10.1016/j.pt.2008.04.001. PMid:18514028.

Brasil. Ministério da Saúde. Manual de Vigilância da Leishmaniose Tegumentar [online]. Brasília: Secretaria de Vigilância em Saúde, Ministério da Saúde; 2017 [cited 2021 Mar 10]. Available from: http://bvsms.saude.gov.br/bvs/publicacoes/manual_ vigilancia_leishmaniose_tegumentar.pdf

Brasil. Ministério da Saúde. Manual de Vigilância e Controle da Leishmaniose Visceral [online]. Brasília: Secretaria de Vigilância em Saúde, Ministério da Saúde; 2014 [cited 2021 Mar 10]. Available from: https://repositorio.observatoriodocuidado.org/ bitstream/handle/handle/2120/manual_vigilancia_controle_leishmaniose_visceral.pdf?sequence=1\&isAllowed=y

Camargo-Neves VL, Gomes AC, Antunes JL. Correlação da presença de espécies de flebotomíneos (Diptera: Psychodidae) com registros de casos de leishmaniose tegumentar americana no Estado de São Paulo, Brasil. Rev Soc Bras Med Trop 2002; 35(4): 299-306. http://dx.doi.org/10.1590/S0037-86822002000400004

Carvalho FS, Wenceslau AA, Albuquerque GR, Munhoz AD, Gross E, Carneiro PLS, et al. Leishmania (Viannia) braziliensis in dogs in Brazil: Epidemiology, co-infection, and clinical aspects. Genet Mol Res 2015; 14(4): 12062-12073. https://doi.org/10.4238/2015. october.5.19.

Colombo FA, Pereira-Chioccola VL, Meira CS, Motoie G, Gava R, Hiramoto RM, et al. Performance of a real time PCR for leishmaniasis diagnosis using a L. (L.) infantum hypothetical protein as target in canine samples. Exp Parasito/ 2015; 157: 156-162. http://dx.doi. org/10.1016/j.exppara.2015.08.014. PMid:26297683.

Centro de Vigilância Epidemiológica "Prof. Alexandre Vranjac" - CVE. Secretaria de Estado da Saúde. Divisão de Zoonoses. Dados Estatísticos, LT - Casos Confirmados de 2007 a 2021. [online]. São Paulo: CVE; 2021 [cited 2021 Mar 10]. Available from: https://www.saude.sp.gov.br/cve-centro-de-vigilancia-epidemiologica-prof.-alexandre-vranjac/areas-de-vigilancia/doencas-detransmissao-por-vetores-e-zoonoses/agravos/leishmaniose-tegumentar/dados-estatisticos

Cupolillo E, Momen H, Grimaldi G Jr. Genetic diversity in natural populations of New World Leishmania. Mem Inst Oswaldo Cruz 1998; 93(5): 663-668. http://dx.doi.org/10.1590/S0074-02761998000500018. PMid:9830535.

Cutolo AA, Teodoro AKM, Ovallos FG, Allegretti SM, Galati EAB. Sandflies (Diptera: Psychodidae) associated with opossum nests at urban sites in southeastern Brazil: a risk factor for urban and periurban zoonotic Leishmania transmission? Mem Inst Oswaldo Cruz 2014; 109(3): 391-393. http://dx.doi.org/10.1590/0074-0276130511. PMid:24789554.

Cutolo AA, Troncarelli MZ, Machado JG, Luvizotto MCR, Von Zuben CJ, Langoni H, et al. Vigilância epidemiológica das leishmanioses no município de Monte Mor, estado de São Paulo, Brasil. Vet Zootec 2009; 16(4): 634-641.

Dantas-Torres F, De Paiva-Cavalcanti M, Figueredo LA, Melo MF, Da Silva FJ, Da Silva AL, et al. Cutaneous and visceral leishmaniosis in dogs from a rural community in northeastern Brazil. Vet Parasitol 2010; 170(3-4): 313-317. http://dx.doi.org/10.1016/j. vetpar.2010.02.019. PMid:20227186.

Dantas-Torres F, Miró G, Baneth G, Bourdeau P, Breitschwerdt E, Capelli G, et al. Canine leishmaniasis control in the context of one health. Emerg Infect Dis 2019; 25(12): 1-4. http://dx.doi.org/10.3201/eid2512.190164. PMid:31742505.

Dantas-Torres F. Dogs as reservoir for Leishmania braziliensis. Emerg Infect Dis 2011; 17(2): 326-327, author reply 327. http:// dx.doi.org/10.3201/eid1702.091823. PMid:21291626.

Dantas-Torres F. The role of dogs as reservoirs of Leishmania parasites, with emphasis on Leishmania (Leishmania) infantum and Leishmania (Viannia) braziliensis. Vet Parasito/ 2007;149(3-4): 139-146. https://doi.org/10.1016/j.vetpar.2007.07.007.

Esteva L, Vargas C, Vargas de León C. The role of asymptomatics and dogs on leishmaniasis propagation. Math Biosci 2017; 293: 46-55. http://dx.doi.org/10.1016/j.mbs.2017.08.006. PMid:28864398.

Falqueto A, Coura JR, Barros GC, Grimaldi Filho G, Sessa PA, Carias VRD, et al. Participação do cão no ciclo de transmissão da leishmaniose tegumentar no município de Viana, estado do Espírito Santo, Brasil. Mem Inst Oswaldo Cruz 1986; 81(2): 155-163. http://dx.doi.org/10.1590/S0074-02761986000200004. PMid:3586998.

Galati EAB. Morfologia e taxonomia: morfologia, terminologia de adultos e identificação dos táxons da América. In: Rangel EF, Lainson R, editors. Flebotomíneos do Brasil. Rio de Janeiro: Fiocruz; 2003. p. 53-175.

Gomes AC. Sand fly vectorial ecology in the State of São Paulo. Mem Inst Oswaldo Cruz 1994; 89(3): 457-460. http://dx.doi. org/10.1590/S0074-02761994000300030. PMid:7476232.

Gomes AHS, Armelin IM, Menon SZ, Pereira-Chioccola VL. Leishmania (V.) braziliensis: detection by PCR in biopsies from patients with cutaneous leishmaniasis. Exp Parasito/ 2008; 119(3): 319-324. http://dx.doi.org/10.1016/j.exppara.2008.02.014. PMid:18442815. 
Gomes AHS, Ferreira IMR, Lima MLSR, Cunha EA, Garcia AS, Araújo MF, et al. PCR identification of Leishmania in diagnosis and control of canine leishmaniasis. Vet Parasitol 2007; 144(3-4): 234-241. http://dx.doi.org/10.1016/j.vetpar.2006.10.008. PMid:17196339.

Google Inc. Google Earth [online]. 2021 [cited 2021 Mar 10]. Available from: https://www.google.com/intl/pt-BR/permissions/ geoguidelines.html

Goto H, Lauletta Lindoso JA. Cutaneous and mucocutaneous leishmaniasis. Infect Dis Clin North Am 2012; 26(2): 293-307. http:// dx.doi.org/10.1016/j.idc.2012.03.001. PMid:22632640.

Grimaldi G Jr, Tesh RB. Leishmaniasis of the New Word: current concepts and implications for the future research. Clin Microbiol Rev 1993; 6(3): 230-250. http://dx.doi.org/10.1128/CMR.6.3.230. PMid:8358705.

Harris E, Kropp G, Belli A, Rodriguez B, Agabian N. Single-step multiplex PCR assay for characterization of New World Leishmania complexes. J Clin Microbio/ 1998; 36(7): 1989-1995. http://dx.doi.org/10.1128/JCM.36.7.1989-1995.1998. PMid:9650950.

Lachaud L, Marchergui-Hammami S, Chabbert E, Dereure J, Dedet JP, Bastien P. Comparison of six PCR methods using peripheral blood for detection of canine visceral leishmaniasis.J Clin Microbio/ 2002; 40(1): 210-215. http://dx.doi.org/10.1128/JCM.40.1.210215.2002. PMid:11773118.

Lainson R, Rangel EF. Lutzomyia longipalpis and the eco-epidemiology of American visceral leishmaniasis, with particular reference to Brazil - A Review. Mem Inst Oswaldo Cruz 2005; 100(8): 811-827. http://dx.doi.org/10.1590/S0074-02762005000800001. PMid:16444411.

Lainson R, Shaw JJ. New World leishmaniasis. The neotropical Leishmania species. In: Collier L, Balows A, Sussman M, editors. Topley and Wilson's microbiology and microbial infectious diseases. 9th ed. London. 1998. p. 241-66. (vol. 5).

Madeira MF, Uchôa CMA, Leal CA, Silva RMM, Duarte R, Magalhães CM, et al. Leishmania (Viannia) braziliensis em cães naturalmente infectados. Rev Soc Bras Med Trop 2003; 36(5): 551-555. http://dx.doi.org/10.1590/S0037-86822003000500002. PMid:14576867.

Marquez ES, de Castro EA, Nabut LB, da Costa-Ribeiro MCV, Dela Coletta Troiano Araújo L, Poubel SB, et al. Cutaneous leishmaniosis in naturally infected dogs in Paraná, Brazil, and the epidemiological implications of Leishmania (Viannia) braziliensis detection in internal organs and intact skin. Vet Parasito/ 2017; 243: 219-225. http://dx.doi.org/10.1016/j.vetpar.2017.07.003. PMid:28807297.

Padilla AM, Marco JD, Diosque P, Segura MA, Mora MC, Fernández MM, et al. Canine infection and the possible role of dogs in the transmission of American tegumentary leishmaniosis in Salta, Argentina. Vet Parasitol 2002; 110(1-2): 1-10. http://dx.doi. org/10.1016/S0304-4017(02)00330-8. PMid:12446084.

Passos VM, Fernandes O, Lacerda PA, Volpini AC, Gontijo CM, Degrave W, et al. Leishmania (Viannia) braziliensis is the predominant species infecting patients with American cutaneous leishmaniasis in the state of Minas Gerais, Southeast Brazil. Acta Trop 1999; 72(3): 251-258. http://dx.doi.org/10.1016/S0001-706X(98)00100-4. PMid:10232781.

Paz GF, Rugani JMN, Marcelino AP, Gontijo CMF. Implications of the use of serological and molecular methods to detect infection by Leishmania spp. in urban pet dogs. Acta Trop 2018; 182: 198-201. http://dx.doi.org/10.1016/j.actatropica.2018.03.018. PMid:29545151.

Pires MQ, Madeira MF, Bittencourt VRE, Pacheco RS. Cutaneous and visceral leishmaniasis co-infection in dogs from Rio de Janeiro, Brazil: evaluation by specific PCR and RFLP-PCR assays. Rev Soc Bras Med Trop 2014; 47(2): 243-246. http://dx.doi. org/10.1590/0037-8682-0007-2013. PMid:24861303.

Pita-Pereira D, Rangel EF, Zwetsch A, Souza GD, Britto C, Alves CR. First report of Lutzomyia (Nyssomyia) neivai (Diptera: Psychodidae: Phlebotominae) naturally infected by Leishmania (Viannia) braziliensis in a periurban area of south Brazil using a multiplex polymerase chain reaction assay. Am J Trop Med Hyg 2009; 80(4): 593-595. http://dx.doi.org/10.4269/ajtmh.2009.80.593. PMid:19346382.

Pittner E, Voltarelli E, Perles TF, Arraes SMMA, Silveira TGV, Lonardoni MVC. Ocorrência de leishmaniose tegumentar em cães de área endêmica no Estado do Paraná. Arq Bras Med Vet Zootec 2009; 61(3): 561-565. http://dx.doi.org/10.1590/S010209352009000300006

Porrozzi R, Costa MVS, Teva A, Falqueto A, Ferrreira AL, Santos CD, et al. Comparative evaluation of enzyme-linked immunosorbent assays based on crude and recombinant leishmanial antigens for serodiagnosis of symptomatic and asymptomatic Leishmania infantum visceral infections in dogs. Clin Vaccine Immunol 2007; 14(5): 544-548. http://dx.doi.org/10.1128/CVI.00420-06. PMid:17314229.

Ramos-E-Silva M, De Moura Castro Jacques C. Leishmaniasis and other dermatozoonoses in Brazil. Clin Dermatol 2002; 20(2): 122-134. http://dx.doi.org/10.1016/S0738-081X(01)00251-6. PMid:11973046.

Reithinger R, Davies CR. Is the domestic dog (Canis familiaris) a reservoir host of American cutaneous leishmaniasis? A critical review of current evidence. Am J Trop Med Hyg 1999; 61 (4): 530-541. http://dx.doi.org/10.4269/ajtmh.1999.61.530. PMid:10548285. 
Rojas E, Scorja JV. Xenodiagnóstico con Lutzomyia youngi en casos Venezolanos de leishmaniasis cutânea por Leishmania braziliensis. Mem Inst Oswaldo Cruz 1989; 84(1): 29-34. http://dx.doi.org/10.1590/S0074-02761989000100006. PMid:2319949.

Roque ALR, Jansen AM. Wild and synanthropic reservoirs of Leishmania species in the Americas. Int J Parasitol Parasites Wildl 2014; 3(3): 251-262. http://dx.doi.org/10.1016/j.jppaw.2014.08.004. PMid:25426421.

Santos FJA, Nascimento LCS, Silva WB, Oliveira LP, Santos WS, Aguiar DCF, et al. First report of canine infection by Leishmania (Viannia) guyanensis in the Brazilian Amazon. Int J Environ Res Public Health 2020; 17(22): 8488. http://dx.doi.org/10.3390/ ijerph17228488. PMid:33207754.

Tolezano JE, Uliana SRB, Taniguchi HH, Araújo MF, Barbosa JAR, Barbosa JER, et al. The first records of Leishmania (Leishmania) amazonensis in dogs (Canis familiaris) diagnosed clinically as having canine visceral leishmaniasis from Araçatuba County, São Paulo State, Brazil. Vet Parasitol 2007; 149(3-4): 280-284. http://dx.doi.org/10.1016/j.vetpar.2007.07.008. PMid:17720321.

Tolezano JE. Ecoepidemiological aspects of american cutaneous leishmaniasis in the State of São Paulo, Brazil. Mem Inst Oswaldo Cruz 1994; 89(3): 427-434. http://dx.doi.org/10.1590/S0074-02761994000300026. PMid:7476228.

World Health Organization - WHO. Investing to overcome the global impact of neglected tropical diseases: Third WHO Report on Neglected Tropical Diseases 2015. Geneva: WHO; 2015. p. 118-26.

World Health Organization - WHO. Leishmaniasis [online]. Geneva: WHO; 2021 [cited 2021 Mar 10]. Available from: https:// www.who.int/news-room/fact-sheets/detail/leishmaniasis\#: :text=Cutaneous\%20leishmaniasis\%20(CL)\%20is\%20the,Middle\%20 East\%20and\%20Central\%20Asia. 